\title{
BECOMING A MOTHER OF A CHILD WITH CANCER: BUILDING MOTHERHOOD ${ }^{1}$
}

\author{
Patrícia Luciana Moreira \\ Margareth Angelo ${ }^{3}$
}

Moreira PL, Ângelo M. Becoming a mother of a child with cancer: building motherhood. Rev Latino-am Enfermagem 2008 maio-junho; 16(3):355-61.

The present study, which was conducted using the Interpretive Interactionism method, had the objective of understanding the experience of becoming a mother of a child with cancer. Seven mothers, whose children were undergoing cancer treatment, took part in semi-structured interviews. The results showed that mothers' role are built in a process that implies the interaction between two themes: LIVING THE TIME OF THE ILLNESS, in which mothers concentrates in themselves, continuously permeated by the uncertainties inherent in the disease, and the need to remove the threats of the child's death; and LIVING A TIME OF STRUGGLE FOR THE CHILDREN'S LIFE, which represents the dimension of mothers' behavior in developing their new role. The articulated theme and the epiphanies allowed identifying the connection between parenthood and temporality, in which the time comes into the dimensions of the development of the mother's role.

DESCRIPTORS: mothers; mother-child relations; medical oncology; pediatric nursing

\section{SER MADRE DE UN NIÑO CON CÁNCER: CONSTRUYENDO LA RELACIÓN}

Este estudio, guiado por el Interaccionismo Interpretativo, tuvo como objetivo comprender la experiencia de ser madre de un niño con cáncer. Siete madres cuyos hijos se encontraban en tratamiento de cáncer participaron de entrevistas semiestructuradas. Los resultados revelaron que el papel de madre es construido en una conjugación entre dos temas: VIVIR EL TIEMPO DE LA ENFERMEDAD, que representa una inspección de la madre consigo misma y vivir una situación de incertidumbre inherente a la enfermedad y la necesidad de alejar la amenaza de la muerte; VIVIR EL TIEMPO DE LUCHA POR LA VIDA DEL NIÑO, que representa la dimensión de los comportamientos de la madre para construir su papel. Los temas articulados a las epifanías permitieron identificar una interrelación entre el parentesco y la temporalidad, en la cual el tiempo se manifiesta en las dimensiones de la construcción del papel de madre.

DESCRIPTORES: madres; relaciones madre-hijo; oncología médica; enfermería pediátrica

\section{TORNAR-SE MÃE DE CRIANÇA COM CÂNCER: CONSTRUINDO A PARENTALIDADE}

Este estudo, guiado pelo Interacionismo Interpretativo, teve como objetivo compreender a experiência de tornar-se mãe de uma criança com câncer. Sete mães, cujos filhos se encontravam em tratamento de câncer, participaram de entrevistas semi-estruturadas. Os resultados revelaram que o papel de mãe é construído numa conjugação entre dois temas: VIVER O TEMPO DA DOENÇA, representando um olhar da mãe para si, vivendo uma situação de incertezas inerentes à doença e necessidade de afastar a ameaça de morte; VIVER O TEMPO DE LUTA PELA VIDA DA CRIANÇA, representando a dimensão dos comportamentos da mãe ao construir seu papel. Os temas articulados às epifanias permitiram identificar inter-relação entre a parentalidade e a temporalidade, na qual o tempo está manifestado nas dimensões da construção do papel da mãe.

DESCRITORES: mães; relações mãe-filho; oncologia; enfermagem pediátrica

${ }^{1}$ Article extracted from Master's Thesis; ${ }^{2}$ RN, M.Sc. in Nursing, e-mail: patriciamoreira@yahoo.com; ${ }^{3}$ RN, Full Professor, email: angelm@usp.br. University of São Paulo School of Nursing, Brazil 


\section{INTRODUCTION}

Children and adolescents with cancer are a group of people who have the uncontrolled proliferation of cells in common and that, with early diagnose and treatment in specialized centers, present a cure rate of approximately $80 \%$. Due to the complexity of the disease and treatment, life of children and their family go through several transformations, and it is necessary to adapt to a new routine and demands that become part of the every day life of the families $^{(1)}$.

In many studies in the area of Pediatric Oncology, mothers are identified as the main source of support and generally take care of children who are sick. Alteration in the biography and the transition of being a mother of a healthy child to being mother of a child with cancer demands a redefinition of selfidentity and the role of mother after confirming diagnosis of their children ${ }^{(2)}$.

Mothers are considered the axes of family structure, and they control raising and educating children, caring for the house and for the health of family members. The role of care taker is expected from them and they have to take care of themselves. To perform this role, mothers ended up creating strategies, such as changing working hours, and giving up their jobs for the sake of the domestic routine and children's demands ${ }^{(3)}$.

Parenthood in the context of children's cancer is justified by the relevance of understanding the dimensions involving the experience of being a mother of a child with cancer. Parenthood is a complex process, not only as a biological relationship result, but also the process of becoming a father and a mother ${ }^{(4)}$. According to the literature, being a mother is playing the role of mother, a multidimensional role encompassing dimensions in the family relation such as closeness, support, monitoring, communication, and acceptance ${ }^{(4-5)}$.

Parenthood can also be defined as the ability to offer care and an environment that enable an excellent growth and development to any human being. The term "family" can be broadly used as a reference in the social environment in which parenthood is conducted ${ }^{(6)}$.

Traditional approach investigates psychological and social aspects of the disease in childhood, representing parenthood in terms on how parents adjust to their children's disease ${ }^{(2)}$. Regarding the experience of mothers in living with their children's cancer, the perspective of care demands thinking on how they take up the responsibility of being mothers facing their children's disease, before focusing on their psychological suffering ${ }^{(7)}$.

Thus, considering issues involving being a mother of a child with cancer, the questions of the survey that guided this study were: regarding children cancer, what would be the dimensions of being mothers in the experience of the diagnosis of cancer in their children? What are the meanings mothers give to their children's disease? How mothers experience their roles in this situation?

We believe that for care, it is essential to understand the experience of having a child with cancer, the meaning given to the disease, to treatment, and to the impact on the family routine, and mothers have to continue playing their roles as mothers. This understanding can give us elements to guide more precisely actions to help and support mothers as people and active subjects in this process. Thus, this study aimed at understanding the experience of becoming mothers of children with cancer.

\section{THEORETICAL AND METHODOLOGICAL REFERENCE}

Symbolic Interactionism was the theoretical perspective of this study, whose main ideas were based on the process of interaction, in which individuals are active and learn to give meaning to things, valuing the meaning human beings give to their experiences. The meaning of things results or emerges from the social interaction human beings establish with each other ${ }^{(8)}$. As a methodological reference, we have chosen Interpretive Interactionism whose objective is to obtain dense and detailed descriptions of experiences biographically important that changed meaning and way people act. These significantly important life experiences receive the name of epiphanies, interaction moments that influence directly the way individuals will act with and in their context. Interpretation is a process that searches for a meaning of an event or experience ${ }^{(9)}$. Considering mothers in the situation of their children's cancer, interacting with other people, with the disease, and with themselves, we believe that the interaction perspective will enable, through interpretation, to know and understand the reality of being mother of a child with cancer defining and writing their history 
Ethical aspects: All aspects present in Resolution CNS 196/96 were observed. Before we started the process of data collection, the project was submitted to examination and was approved by the Ethical Research Committee of the Nursing School at the University of São Paulo. After this, we have requested authorization of the institution of the Pediatric Oncology Institute - IOP, in the city of São Paulo, that allowed data collection in the place. Acceptance of the participants in sharing their stories was made official through Informed Written Consent.

Participants of the study: Seven mothers of children undergoing cancer treatment took part in the study. Mothers were between 24 and 41years old, six were married and one was a widow. All of them had children undergoing chemotherapy at the time of interview; they were the ones with the children during treatment. Three mothers were coming from other states. Two mothers developed professional activity outside the household and one in the household. The others had left their activities to stay with their children during treatment. The number of participant mothers was not previously determined. Data collection was performed at the time we realized the absence of new data, and the development and densities in the category were achieved.

Data collection: Data collection was guided by the Biographic method and occurred in the period from December 2005 to April 2006. The strategy to obtain data was semi-structured interview guided by the question: "Please, tell me about your experience of having a child with cancer." Narratives were totally recorded and transcribed after interview was performed.

Data analysis: For data analysis, steps recommended by Interpretive Interactionism were followed $^{(9)}$. The stages of this method are: defining the issue in study; deconstruction and critical analysis of the conceptions of the phenomenon; understanding the phenomenon, located and placed into the context; reduction of the phenomenon, isolating it in the context in which it occurred through finding and isolating key sentences; building the phenomenon, articulating data again from the meaning coming from the previous sentence; contextualization, placing the phenomenon back in the context, interpreting it and giving it meaning.

Thus, after transcription of interviews and reading biographic narrative of mothers, the experiences reported were broken into small sentences, enabling identification of experience units.
From a detailed process of understanding semantic load, and the evidences contained on the narratives, experience units are compared one with another with its meaning on the experience, according to their similarities and differences. Units connected by the same meaning were grouped, allowing for identification of categories and subcategories. Comparison and integration of categories articulated on the experience allowed to identify themes and sub themes that revealed meanings and experiences in the universes forming these experiences. Last, when we understood how the construction of the role of mothers appears in the experience of becoming a mother of a child with cancer, we could identify the moments that were intensively remembered. These moments that carry feelings that will never be forgotten are called revealing moments, or epiphanies, and bring a redirection to mothers' lives and to the construction of their role facing the cancer of their children.

\section{RESULTS}

Comprehension and analysis of categories and subcategories allowed for 2 themes to be identified: LIVING THE TIME OF THE ILLNESS, formed by the sub themes BECOMING A MOTHER OF A CHILD WITH CANCER and TAKING THE RISK OF TREATMENT, and LIVING A TIME OF STRUGGLE FOR THE CHILDREN'S LIFE, formed by the sub themes PREPARING FOR A TIME OF BATTLE and FIGHITING FOR THE CHILDREN'S LIFE.

LIVING THE TIME OF THE ILLNESS: Reveals a conversation of mothers with themselves, a view of themselves as mothers. The inner work of mothers in this new condition starts with acceptance that their children have cancer and is continuously marked by uncertainties of the disease and the need to remove the idea of death of the children. DISCOVERING ONESELF AS MOTHERS OF CHILDREN WITH CANCER it is to live the time of diagnosis, experiencing a sudden change, and facing the threat the disease represents to their children's life. Despite all this, mothers try to recover their balance to start the difficult path of cancer. Discovering oneself as mothers of children with cancer is Not wanting to waste time, revealing the need for acting fast to remove the possibility of losing their children. It is also living the uncertainty regarding treatment that represents doubts of mothers about the disease, on how to act and take care of their children, and about the future of their children. In this time of discovery, mothers perceive that it is 
necessary to accept the idea of being a mother of a child with cancer, adjusting to a new situation and going on with their journey.

Then, that thing of diagnosis came, changing from one hospital to another, thus, being in contact with other mothers that I met and adjusting to the idea of being, mother... Many children are healed and others unfortunately are not, but then each case is one case. But for me, now we are used to the situation, but in the beginning it was very, very hard and it is still hard, but it is harder in the beginning... It was like that ... (Mother 6)

LIVING THE TIME OF THE ILLNESS is a time of TAKING RISKS WITH THE TREATMENT, this was their only option regarding the possibility of losing their children. Mothers live a Time of fear that represents a time of darkness, in which what will happen next is a doubt. Taking risks with treatment is experiencing a feeling of helplessness, since when they see their children suffering, mothers notice there are things they would like to do to relieve this suffering but they cannot. To live the time of the disease, you must live the present, focusing on now. It entails a decision of mothers on how to use best the time they have with their children, and each day is a new opportunity to fight. At the same time, they must believe that the time of the disease will end, that their children one day will be free from the disease. The hope they will beat the disease is the anchor for them not to give up, encouraging their decisions.

Even though you only see darkness, this tunnel, of bad things, things that give you no hopes, you really can believe that in the end, after everything you go through, in the end there will always be light. And this light will be huge, will bring happiness, everything you think is lost, you will see that nothing is lost, you just have to search for, trust, believe, give yourself, that you will beat the disease, the you can do everything. (Mother 3)

LIVING A TIME STRUGGLING FOR CHILDREN'S

LIFE: This shows the dimension of mothers' behaviors, that are expressed in the interactions with themselves, with their children and with all the elements involved in the experience of their children's disease, showing the construction of their role as mothers of children with cancer. It represents the search of mothers for PREPARING THEMSELVES TO A TIME OF BATTLE, a difficult time brought by the disease. Mothers try to know the enemy, that is, know more about cancer, searching for important elements to get strong. As they get to know the disease, they also get to meet people experiencing it. This gives them hope and makes them realize they are not the only one struggling. Preparing themselves for a time of battle is a time of making choices. The life of their children and the new demands of the disease are the focus of attention and trigger all the decisions, demanding a reorganization of roles and redirecting life. Children are the priority in this time of battle, it is necessary to choose a safe place to treat children based especially on the safety the institution gives to mothers, children, and the family.

Because I know about the disease, I mean, when I found out, I did not think twice, I came to S.P (São Paulo), I knew my younger daughter would be ok, there is my mother, my sisters, there are many people to taker care of her there (...) I mean, I only thought about her at the time, I did not think about my job that I left, I did not think about anything, nothing... She was my only idea. The objective was her, it was to live here with her healed, I believe she is, I did not think, I did not get worried about my job, I really did not think. So much so, that when I came here, I knew there was a support center. When I came here, my husband was concerned: "You are crazy, you will go there, you do not know about the structure there". I looked at him and I said: "Look, P., I can be there seated on a chair next to my daughter, but as long as I bring her back healed! This for me is no problem at all!" When I arrived here and saw all this structure, it was nothing like he expected, so much so, that he came too, he saw how good the structure was, there was a support house if I wanted to stay there...(Mother 5)

STRUGGLING FOR THE CHILDREN'S LIFE represents the behaviors of mothers when they are next to their children all the time and experience the battle together with their children. Mothers try to be with them at all times in their battle against cancer. Mothers try to be near and available for children at all times of the treatment, becoming full time mothers, with no rest, and living their lives for the needs of their sick children. Struggling for the children's' life is also protecting the children from the threats of the disease. Their care is a special care, protecting the integrity of children, and enabling them to continue living their cancer history. To protect the children, mothers observe the details, even those details that would probably not be noticed before the disease. When they are struggling against the disease, mothers notice that it is essential to be a support to the children, expressing several behaviors of mothers to prepare their children for the battle against cancer. This means not allowing them to be discouraged, making them strong to the battle, and giving the necessary subsides for them to face the disease and not give in, keeping the faith that everything will be ok. Mothers talk to children about cancer and treatment, without lying or hiding the facts, and being aware on how and when to talk about the disease. To 
fight, mothers realize they need to get strong for the battle. They get strength in the faith in God, and in the hope of a time without the disease. Mothers take up the struggle for their children's life, keeping themselves tough and believing they can stand all that suffering. They feel they can overcome any barrier to be next to their children, but for that, they need to take care of themselves and their family. Thus, when they experience the struggle for their children's life, protecting and being a support for them, aiming at getting strong and getting their children strong to fight the disease, mothers can feel more like mothers. They can give themselves to their children, doing their best, and overcoming any obstacles there may be to see their children well. Everything they do is not because they have to, but because of the love they have for their children. Their love seems to increase and become stronger than it was before the disease. This love, together with the desire of not wanting their time with their children to get to an end, make them act and fight together with their children.

(...) I try to; I am a very positive person, always thinking about the best, always thinking that everything is going to be fine. I will not tell you that this is easy, it is not easy. But the struggle is huge, we have to be strong all the time, even to give them strength, because they need it. (...) So, when I told T. what she had, I told her like that, she was seven and I said: You have a disease, I did not hide anything, I said: you have cancer, it is not easy to heal as a cold, a cold is much easier... It will be a bit hard, but we are going to take care of you, and we will win. (...) It was really a time that I got closer to $T$. because when children are healthy, we give love, we talk, we have always been very close, but when you are going through such a situation, I think you get closer... Especially being here, my whole time is for her! (...) I always start giving support to her, trying to guide her in everything she needs, explaining everything I can to her, and taking care of her things, her diet. Taking care of myself as well, because I have to (Mother 7 ).

When we try to understand the experience of being mothers of a children with cancer, we realize there is a interlink between parenthood and temporality, that is, between becoming full time mothers and playing the role of mothers and the time which is one of the essences in the construction of this role. Thus, the following epiphanies could be identified:

NOTICE THAT THEIR TIME WITH THE CHILDREN IS THREATENED: When they receive the diagnosis of their children's cancer, mothers notice that not only the life of their children is threatened by the disease, but also their time as mothers of that children is under risk. From that moment, all decision making process take part, together with several actions of the mothers to prevent their time with their children to be over.

DECIDING THAT THIS IS THE TIME OF THE CHILDREN: When they see their children's life under risk, mothers face a situation where it is essential to establish a priority to their lives, that will be the focus of concern and that will lead to all decision making. Deciding that this is the time of the children is to decide that they will be the most important thing in their lives and in the family, so that every body can get ready for the hard time that is coming.

FIGHTING FOR THEIR CHILDREN GEARED BY LOVE: Mothers believe that fighting for their children's life is their duty as mothers. They are in the front line, meaning they will take up the fight together with children, geared by their love as mothers, as if that was also their battle, living the experience in full. This is a time of sacrifice, where mothers try to do everything they can to keep children as far away as possible from the danger the disease represents.

The way these revealing moments are expressed in the experience of being mothers of children with cancer is represented in the Figure 1.

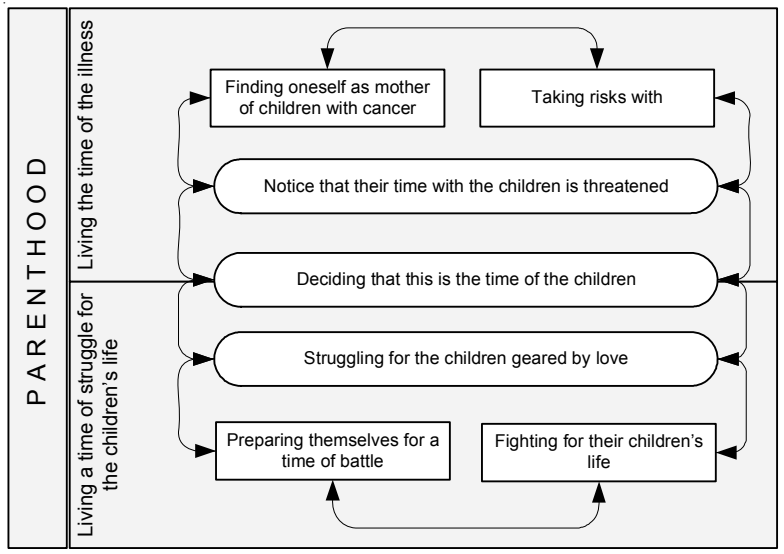

Figure 1 - Becoming mothers of children with cancer: building a parenthood

\section{DISCUSSION}

Parenthood was the anchor in the search for understanding being mothers of children with cancer, considering that being a mother is to play the role of mothers. We have noticed that time is revealed as one of the essences of parenthood. Time and parenthood are expressed by the behaviors of mothers, in the decision making, in the construction 
of their role, and in the meaning given to the disease and to being mother. Temporality is present on the threat the disease represents on their time with the children; in the decision making, and in the reorganization of mothers considering the time of the disease and the children; and in the time in which the focus of their life is fighting for their children's life, performing the role they believe it is theirs.

The essence of maternity was expressed in contextual factors such as the disease threatening the life and the commitment of mothers to take care of their children. For mothers caring for children that died of AIDS, taking care of their children was what they could do as mothers, listening and answering to the call of their conscious to do what they believed to be their duty as mothers, women, and human beings ${ }^{(10)}$. Protective care is part of all actions of mothers with children, and to give it, mothers feel the need to control the situation ${ }^{(11)}$. In our study, this conscious call is experienced by mothers when fighting for the life of children. Their duty as mothers is present in their actions and in their role as mothers performed by the meaning they give to being mothers of children with cancer. Protecting the children entails also an intense surveillance, and the protective care is mediated by time. In the present study, mothers, when fighting for their children's life performing the role of mother, try to protect their children all the time, keeping them from any worsening to their condition and possibility of loss. In the interrelation between parenthood and time, protecting their children is a strategy for that time as mothers not to end.

Becoming mothers of children with cancer can be considered a transition experience. Transitions in people's lives may be planned or occur unexpectedly. Transitions in life may be many and have been described as paths in which people face changes ${ }^{(12)}$. The experience in transition may occur due to changes in health situation and in the disease of individuals, and are considered complex and multidimensional, and time is among their priority. Transition is extension of time that starts with the first signs of change, it flows through a period of instability, confusion and anguish and it ends with a new beginning or a period of stability ${ }^{(13)}$.

Living the diagnosis of children with cancer is a sudden and unplanned experience, thus the role of mothers, which is not static, needs to be reviewed, building a new role according to the unexpected. The experience of being mothers of children with cancer is a break in their biography. The time of experiencing their children diagnosis and discovering oneself as mothers of children with cancer is marked by instability of a life invaded by the disease. As time goes by, mothers decide to take risks with treatment understanding that this is the time of children and to fight the disease. They do everything they can to remove the threat of death represented by the disease.

According to the assumptions of Symbolic Interactionism, we understand that the role of mothers is multidimensional and is expressed by their behaviors with the objective of removing the possibility of losing their children. Meanings they give to cancer are expressed by the actions, reflections, reorganizations, decisions, and responsibilities. From the moment mothers define their situation as mothers of children with cancer interacting with the "self" and the others, their actions start, that is, they perform their duties with the objective of fighting for the life of their children all times.

\section{FINAL CONSIDERATIONS}

Considering the lack of evidences on the literature focusing on the understanding of the multidimensional role of mothers and the construction of parenthood in the experience of becoming mothers of children with cancer, we believe this study may contribute to build a new thinking on this experience. Results show how mothers, even suffering due to the situation of their children's disease, follow their journey as mothers and face the struggle against cancer with their children. New surveys may and must be performed in this sense, aiming at building knowledge on parenthood in the situation of the disease.

"In the adventure of each family, it comes to us, sometimes only as a pit stop. It would be good for them if, just as the inn on the middle of the road, they could find someone waiting to serve them, relieve their suffering, where they could reestablish themselves, regaining their strength to continue with the path"(14). Understanding the experience lived by mothers of children with cancer in building parenthood gives elements that may bring about actions to help and support care of nursing in pediatric oncology more precisely. We believe that these actions may meet the real needs of mothers and ensure living this experience fully in the complex path of children's cancer. 


\section{REFERENCES}

1. Costa JC, Lima RAG. Crianças/adolescentes em quimioterapia ambulatorial: implicações para a enfermagem. Rev Latino-am Enfermagem 2002; 10(3):321-33.

2. Young B, Dixon-Woods M, Findlay M, Heney D. Parenting in a crisis: conceptualising mothers of children with cancer. Soc Sci Med. 2002; 55(10):1835-47.

3. Martins VB. Angelo M. A organização familiar para o cuidado dos filhos: percepção das mães em uma comunidade de baixa renda. Rev Latino-am Enfermagem. 1999; 7(4):89-95.

4. Silva MCP, Solis-Ponton L. Ser pai, ser mãe - parentalidade: um desafio para o terceiro milênio. São Paulo: Casa do Psicólogo; 2004.

5. Snider JB, Clements A, Vazsonyi AT. Late adolescent perceptions of parent religiosity and parenting process. Fam Proc. 2004; 43(4):489-502.

6. Franck LS, Callery P. Re-thinking family-centred care across the continuum of children's healthcare. Child Care Health Dev. 2004; 30(3):265-77.

7. Clarke JN, Fletcher PC, Schneider MA. Mother's home health care work when their children have cancer. J Pediatr Oncol Nurs. 2005; 22(6):365-73.

8. Charon JM. Symbolic Interacionism. An introduction, on interpretation, an integration. New Jersey: Prentice Hall; 1989.

9. Denzin NK. Interpretive Interacionism. California: SAGE Publications; 1989.

10. Nelms TP. A most wonderful, tragic experience: the phenomenon of mothering in caregiving an adult son with AIDS. J Fam Nurs. 2002; 8(3):282-300.

11. Judson LH. Protective care: mothering a child dependent on parenteral nutrition. J Fam Nurs. 2004; 10(1):93-120.

12. Liddle J, Carlson G, McKenna K. Using a matrix in life transition research. Qual Health Res. 2004; 14(10): 1396417.

13. Meleis AI, Sawyer LM, In EO, Messias, DAKH, Schumacher $\mathrm{K}$. Experiencing transitions: an emerging middlerange theory. Adv Nurs Sci. 2000; 23(1):12.

14. Angelo M. Abrir-se para a família: superando desafios. Fam Saúde Desenv. 1999; 1(1/2):7-14. 